\title{
Gene Distance Metric
}

National Cancer Institute

\section{Source}

National Cancer Institute. Gene Distance Metric. NCI Thesaurus. Code C72648.

A mathematical method for calculating a relatedness score for genes. 